\title{
Genetic similarity among Eurasian subspecies of boreal owls Aegolius funereus
}

\author{
Marni E. Koopman, David B. McDonald, Gregory D. Hayward, Katrine Eldegard, Geir A. Sonerud and \\ Sergey G. Sermach
}

\begin{abstract}
Koopman, M. E., McDonald, D. B., Hayward, G. D., Eldegard, K., Sonerud, G. A. and Sermach, S. G. 2005. Genetic similarity among Eurasian subspecies of boreal owls Aegolius funereus. - J. Avian Biol. 36: 179-183.
\end{abstract}

\begin{abstract}
Boreal owls Aegolius funereus (referred to as Tengmalm's owls in Europe) breed in boreal forests throughout the Holarctic region and in high-elevation subalpine forests further south. They are currently classified as seven subspecies; six found throughout Eurasia, and one in North America. The geographic distribution of boreal owls in North America and Eurasia is similar, as are their patterns of dispersal and irruption. Because a recent genetic study of boreal owls in North America found very little genetic differentiation among widely disparate locations, we expected that boreal owls in Eurasia similarly would have very little genetic differentiation. Using seven microsatellite markers, we analyzed genetic samples from 275 boreal owls in North America, 36 in Norway, and five in eastern Russia. We found no detectable genetic differentiation between Norwegian and Russian owls, but notable differentiation between North American and Eurasian owls. Low intra-continental genetic differentiation likely results from high rates of long-distance dispersal among subpopulations of boreal owls. In light of these results, we recommend further genetic sampling of boreal owls throughout Eurasia in order to determine whether six separate subspecies here are warranted.
\end{abstract}

M. E. Koopman (correspondence), D. B. McDonald and G. D. Hayward, Department of Zoology and Physiology, University of Wyoming, Laramie, WY 82071. K. Eldegard and G. A. Sonerud, Department of Ecology and Natural Resource Management, Agricultural University of Norway, P.O. Box 5003, N-1432 As, Norway and S. G. Sermach Institute of Biology and Soil Sciences, Vladivostok, Russia. Present address of M. E. Koopman: 1133 Emma St., Ashland OR 97520, USA. E-mail:marnikoopman@yahoo.com

A variety of holarctic avian taxa were subjected to genetic investigation with two dominant patterns of genetic structure emerging. First, intra-continental genetic differentiation is often minimal or lacking (Kryukov and Suzuki 2000, Omland et al. 2000, Zink et al. 2002). Second, genetic differentiation between North American and Eurasian populations of circumboreal taxa is often great enough to warrant reclassification of many conspecifics as separate species (listed in Zink et al. 2002). In contrast, species that are morphologically uniform can sometimes harbor cryptic genetic variation and/or discrete genetic breaks (Zink et al. 1995, Omland et al. 2000). Such patterns may provide insight into the phylogeographic history of a species and its populations (Avise 2000), in addition to modern gene flow patterns.

Boreal owls Aegolius funereus (referred to as Tengmalm's owl in Europe) breed in boreal forests throughout the Holarctic region and in high-elevation subalpine forests further south. Seven subspecies are currently recognized; six throughout Eurasia and one in North America (Mysterud 1970, Cramp 1985). Of the former six, three are found across the boreal forests of Eurasia (A. f. funereus, A. f. sibericus, and A. f. magnus), and three others are found south of the boreal forest, in patchily distributed islands of high-elevation coniferous forest in the Caucasus ( $A$. $f$. caucasicus), in the Tien Shan, Kazakhstan (A. f. pallens), and in central China

JOURNAL OF AVIAN BIOLOGY 
(A. f. beickianus; Fig. 1). The North American subspecies (A. f. richardsoni) is distributed throughout boreal forests in Canada and Alaska, but its distribution also extends south in high-elevation, subalpine forests in the Rocky Mountains (Hayward et al. 1987).

Across the boreal forests in Eurasia, boreal owls vary from dark brown and smaller (mean female wing $=176$ $\mathrm{mm}$ ) in Fennoscandia to light grey and larger (mean female wing $=187 \mathrm{~mm}$ ) in Russia, east of the Kolyma River (Dement'ev and Gladkov 1966, Cramp 1985). However, individuals that are captured within the range of one subspecies often have coloration that is more characteristic of another subspecies, and supposed hybrids have often been documented (Dement'ev and Gladkov 1966). Distinctions among Eurasian subspecies are unclear and subspecific boundaries consist of the Ural Mountains in the west and the Kolyma river valley in the east (Fig. 1; Mysterud 1970). Boreal owls may form a gradient in size and coloration across the northern boreal forest (Dement'ev and Gladkov 1966, Cramp 1985).

The ecology of boreal owls in Eurasia is extremely similar to that in North America. The boreal owl is a cavity nesting nocturnal owl, subsisting mainly on small mammals, in particular microtine rodents (Cramp 1985, Hayward et al. 1993). Boreal owls, in particular females and juveniles, often disperse long distances when microtine populations decline (Löfgren et al. 1986, Korpimäki et al. 1987, Sonerud et al. 1988, Hipkiss et al. 2002). This nomadic dispersal pattern is likely an adaptation to the regional spatial asynchrony in population cycles of microtine rodents (Mysterud 1970). A predicted effect of periodic nomadism is taxonomic homogeneity among boreal owls caused by high rates of gene flow (Mysterud 1970). Boreal owls showed no genetic differentiation across the boreal forests of North America and little throughout the subalpine forest as far south as southern Colorado (Koopman 2003). Because boreal owls on both continents exhibit such similar ecology and distribution, gene flow data collected in North America

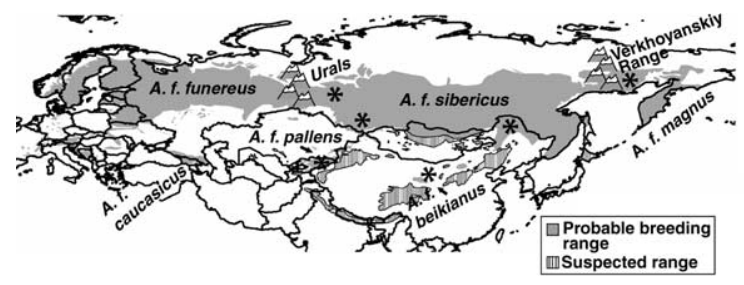

Fig. 1. Documented and suspected range of boreal owls in Eurasia. Subspecific boundaries are currently unclear, and widespread intergradation has been documented (Cramp 1985). Documented areas of hybridization or sightings of subspecies other than the one known to occur in an area are marked with asterisks. Range map is based on GIS coverages and other information amalgamated from multiple sources (Ripley 1961, Dement'ev and Gladkov 1966, de Schauensee 1984, Flint et al. 1984, Cramp 1985, Brazil 1991, Roberts 1991, Grimmett 1999, Kazmierczak 2000). allows us to make inferences about their Eurasian counterparts. Here, we address the hypothesis that Eurasian boreal owls in the boreal forest are also genetically indistinguishable, even across subspecific boundaries, but may differ notably from American boreal owls due to the dispersal barriers caused by the North Atlantic Ocean and the Bering Strait.

\section{Methods}

We obtained genetic samples from 36 unrelated, breeding adults of $A . f$. funereus from Norway $\left(\right.$ c. $61^{\circ} \mathrm{N}$, $11^{\circ} \mathrm{E}$; see Beheim et al. 2002) and five unrelated individuals of $A . f$. sibericus from eastern Russia (c. $44^{\circ} \mathrm{N}, 135^{\circ} \mathrm{E}$ and $60^{\circ} \mathrm{N}, 151^{\circ} \mathrm{E}$ ), almost at the eastern edge of their Palearctic range. We analyzed these samples using the same seven microsatellite loci (GenBank \# AY257171-77) as were used for 275 samples of unrelated A. f. richardsoni from North America (Koopman et al. 2004). Because of small sample sizes for A. f. sibericus, we were not able to perform rigorous analyses of the resulting data, but here we present graphical evidence for genetic similarity among Eurasian subspecies of boreal owls. We calculated allele-sharing distances among individuals sampled from the three different subspecies and created a Neighbor-joining tree (Fig. 2) using PHYLIP (Felsenstein 1989). With data from $A . f$. funereus and $A$. $f$. richardsoni, we calculated CavalliSforza chord distances and created a UPGMA tree in PHYLIP. We calculated Weir and Cockerham's (1984) measure of genetic differentiation, $\theta$ (equivalent to $F_{\mathrm{ST}}$ ), between $A$. f. funereus and A. f. richardsoni in FSTAT v 2.9.3.2 (Goudet 1995), using 36 samples from unrelated individuals (18 males and 18 females) from each

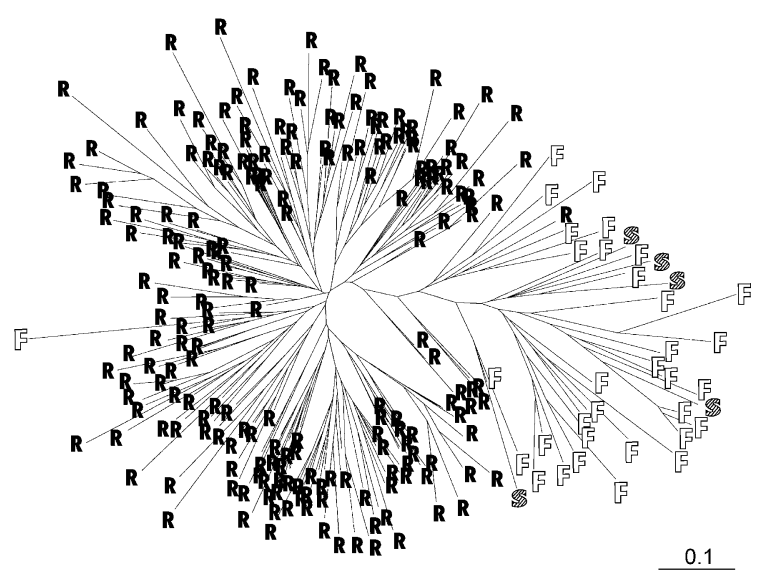

Fig. 2. Neighbor-joining tree of allele-sharing distances for three different subspecies of boreal owls. North American boreal owls (A. f. richardsoni $[\mathbf{R}]$ ) segregated from Eurasian boreal owls ( $A$. $f$. funereus $[\mathbf{F}]$, and $A$. $f$. sibericus $[\mathbf{S}]$ ), but Eurasian subspecies did not segregate from each other, indicating genetic similarity across the continent. 
subspecies, collected in Norway and in southcentral Canada.

\section{Results}

A. f. funereus and A. f. richardsoni fell out separately on both the Neighbor-joining tree of allele-sharing distances (Fig. 2), and the UPGMA tree of Cavalli-Sforza genetic distances (Fig. 3). However, A. f. sibericus did not segregate from $A$. $f$. funereus on the allele-sharing distance tree. Rather, the two Eurasian subspecies clustered together, as did the one North American subspecies, with two individual outliers. Genetic differentiation between $A$. $f$. funereus and $A$. $f$. richardsoni $(\theta=0.37,95 \% \mathrm{CI}=0.16-0.59)$ was considerable. In contrast, genetic differentiation among North American subpopulations, including Alaska, Canada, Idaho, Montana, Wyoming, and southern Colorado, was close to zero $(\theta=0.004$; Koopman 2003). Because of small sample sizes, we were unable to include $A$. $f$. sibericus in our calculations of theta.

\section{Discussion}

A. $f$. funereus and $A$. $f$. sibericus were genetically indistinguishable even though samples were collected from extreme western and eastern Eurasia. While this evidence strongly supports our hypothesis that there is only one genetically distinct subspecies in the boreal forest of Eurasia, we stress that more samples are needed in order to make firm conclusions.

Due to similar ecology and geographic distribution among boreal owls in the Old World and in the New World, gene flow data from North America (Koopman

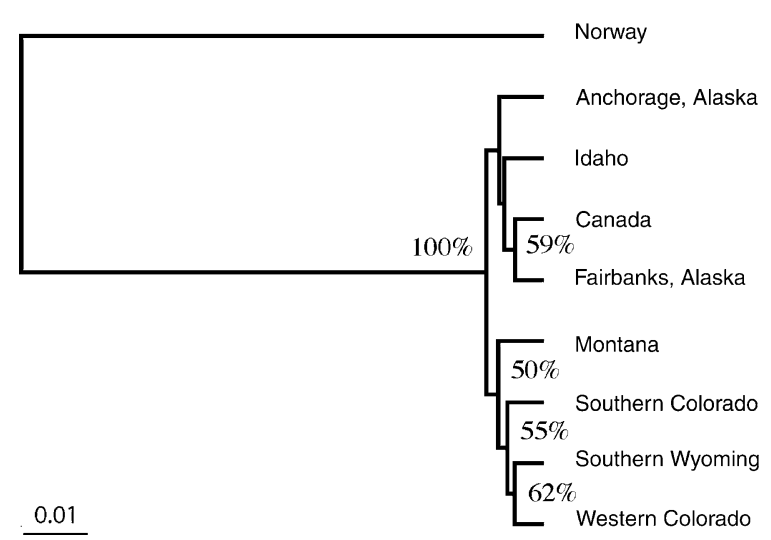

Fig. 3. Unrooted UPGMA tree of Cavalli-Sforza chord distances among eight subpopulations of boreal owls in North America (A. f. richardsoni), based on 275 samples, and one population of boreal owls in Norway ( $A$. $f$. funereus), based on 36 samples. Percent support for each node based on agreement among trees from 1000 bootstrapped data sets.
2003) provides insight into the genetic structure of Eurasian boreal owls. In North America, no genetic differentiation was found among boreal owls sampled in Alaska and Manitoba, almost $3500 \mathrm{~km}$ apart in the boreal forest (Koopman 2003). The Canadian Rockies separate these sample locations and represent a geographic barrier equivalent to the Urals; both ranges have peaks around $2,000 \mathrm{~m}$ high and run in a north-south orientation, effectively bisecting the range of the owls. In the Rocky Mountains, south of the boreal forest in North America, extremely low genetic differentiation and high movement rates were found among all subpopulations, even when patches of habitat were separated by over $200 \mathrm{~km}$ of treeless matrix (non-habitat). There was also a pattern of gene flow that indicated high levels of movement from boreal forest populations south to Rocky Mountain populations, probably due to irruptive movement during periods of low prey availability.

Eurasian boreal owls exhibit a similar spatial structure to those in North America, with large continuous populations in the north and smaller, patchily distributed populations at high elevations, further south. Unfortunately, the full extent of the range of boreal owls in Asia, south of the boreal forest, has not been documented (Fig. 1). There are only a handful of breeding records for boreal owls in India, Pakistan, China, Kyrgyzstan, and Tajikistan, even though large patches of suitable habitat may be available. We suspect that boreal owls are much more widespread than is reflected in the current literature but that they often go undetected because they are highly nocturnal and found at high latitudes or high elevations, where fewer people reside and fewer scientific investigations are conducted. Although boreal owls are found commonly throughout the Rocky Mountains of the western United States, breeding populations went undocumented as late as 1980 (Hayward et al. 1987, Stahlecker and Rawinski 1990), with some parts of their range suspected but still undocumented. Individual subpopulations throughout such areas as eastern Kazakhstan, Kyrgyzstan, Tajikistan, northern Pakistan and India, and western China may not be isolated from populations further north, or from each other, if there are surrounding undocumented subpopulations and high rates of gene flow.

Based on our gene flow data from North America, we suggest that high levels of movement likely occur among patchily distributed subpopulations found throughout northern and central China and surrounding countries. Also, due to well-documented irruptive movement among northern boreal forest populations on both continents, we expect that periodic mass emigration to southern habitat patches acts to further homogenize southern subpopulations and overwhelm local adaptations to southern conditions (cf. Kawecki and Holt 2002). 
In contrast to a lack of intra-continental genetic structure, high genetic differentiation between $A . f$. funereus and $A$. f. richardsoni indicates extreme divergence between Old World and New World boreal owls. While high dispersal rates allow for genetic homogenization within each continent (Mysterud 1970), even when habitat is patchily distributed, exchange between the continents is limited to extremely rare occurrences across the Bering Strait (Pyle 1997). Such rare occurrences may account for the outliers seen in Fig. 2, but these outliers may also be an artifact of the high mutation rates of microsatellite markers, and they may represent homoplasy rather than gene flow. Further investigation into the level of divergence between these subspecies using more slowly evolving markers such as mtDNA restriction sites or cytochrome $b$ sequences would assist in determining whether separate species status may be warranted. Among several other taxa, New World and Old World subspecies have been reclassified as separate species due to significant genetic differences (reviewed in Zink et al. 2002). Examples include American and Eurasian three-toed woodpeckers (suggested latin names: Picoides dorsalis and P. tridactylus; Zink et al. 2002), marbled and long-billed murrelets (Brachyramphus marmoratus and B. perdix; AOU 1998), blackbilled and Eurasian magpies (Pica hudsonia and P. pica; AOU 2000), American and water pipits (Anthus rubescens and A. spinoletta; AOU 1998), and gray-crowned rosy finches and rosy finches (Leucosticte tephrocotis and L. arctoa; AOU 1998).

We were unable to obtain samples from subspecies south of the boreal forest in Eurasia, and therefore can not make strong inferences about their genetic autonomy, although we suspect it is lacking. However, the range of $A$. $f$. caucasicus is highly disjunct compared to North American subpopulations and other Eurasian subspecies; it may indeed represent a genetically distinct subspecies. Genetic samples from the Caucasus might allow us to determine the limits to dispersal for this highly mobile owl, in addition to providing clarification of the number of genetically distinct subspecies of boreal owls worldwide. Further efforts should include surveys for boreal owls in suitable habitat in multiple countries, especially along the western border of China, collection of genetic samples from all subspecies, and development of additional genetic markers for a thorough assessment of the taxonomy of boreal owls.

Acknowledgements - We thank O. Heie and H. Vognild for field assistance in Norway and L. Ayers, M. Suedkamp, J. Bennett, J. Carpenedo, S. Dubay, T. Heekin, the Hayward family, S. Koopman, T. Hampton, K. Ott, P. Sutherland, K. Keffer, S. Mullins, and J. Bassinger for field assistance in North America. G. Bjørnstad provided instructions on blood sampling and DNA extraction of blood samples. C. Schultz, T. Holland, T. Swem, E. Taylor, B. Dittrick, L. Moorehead, J. Duncan and T. Bodreaux collected and sent us samples. Additional boreal owl genetic samples were provided by the Bell Museum, Manitoba Conservation, the University of Alaska
Museum, and the Burke Museum. The Directorate for Nature Management and the National Animal Research Authority in Norway granted permission to trap the owls and sample blood. Comments from four anonymous reviewers greatly improved the manuscript. Financial support was provided by Global Forest (GF-18-2000-130), The Research Council of Norway, the Nansen Endowment, U.S. Forest Service Rocky Mountain Research Station, and awards from the American Museum of Natural History, Sigma Xi, the Department of Zoology and Physiology and the Institute of Environment and Natural Resources at the University of Wyoming.

\section{References}

American Ornithologists' Union 1998. Check-list of North American birds, 7th ed. - American Ornithologists' Union, Washington, DC.

American Ornithologists' Union. 2000. Forty-second supplement to the American Ornithologists' Union check-list of North American birds. - Auk 117: 847-858.

Avise, J. C. 2000. Phylogeography: the history and formation of species. - Harvard University Press, Cambridge, MA.

Beheim, J., Eldegard, K., Bjørnstad, G., Isaksson, M., Sonerud, G., Heie, O. and Klungland, H. 2002. DNA polymorphism in boreal owls (Aegolius funereus). - J. Rapt. Res. 36: $218-$ 219.

Brazil, M. A. 1991. The Birds of Japan. - Smithsonian Institution Press, Washington D.C.

Cramp, S. 1985. Handbook to the birds of Europe, the Middle East, and North Africa. - Oxford University Press, Oxford, UK.

Dement'ev, G. P. and Gladkov, N. A. 1966. Birds of the Soviet Union. Vol. 1. - Smithsonian Institution and National Science Foundation, Washington D.C.

de Schauensee, R. M. 1984. The Birds of China. - Smithsonian Institution Press, Washington D.C.

Felsenstein, J. 1989. PHYLIP-Phylogeny inference package (Version 3.2). - Cladistics 5: 164-166.

Flint, V. E., Boehme, R. L., Kostin, Y. V. and Kuznetsov, A. A. 1984. A field guide to the birds of the USSR, including eastern Europe and Central Asia. - Princeton University Press, New Jersey.

Grimmett, R. 1999. Birds of India, Pakistan, Nepal, Bangladesh, Bhutan, Sri Lanka, and the Maldives. - Princeton University Press, New Jersey.

Goudet, J. 1995. FSTAT (ver. 1.2): a computer program to calculate F-statistics. - J. Hered. 86: 485-486.

Hayward, G. D., Hayward, P. H. and Garton, E. O. 1987. Revised breeding distribution of the boreal owl in the northern Rocky Mountains. - Condor 89: 431-432.

Hayward, G. D., Hayward, P. H. and Garton, E. O. 1993. Ecology of boreal owls in the northern Rocky Mountains, USA. - Wildlife Monogr. 124: 1-59.

Hipkiss, T, Hörnfeldt, B., Lundmark, Å. and Norbäck, M. 2002. Sex ratio and age structure of nomadic Tengmalm's owls: a molecular approach. - J. Avian Biol. 33: 107-110.

Kawecki, T. J. and Holt, R. D. 2002. Evolutionary consequences of asymmetric dispersal rates. - Am. Nat. 160: 333-347.

Kazmierczak, K. 2000. A field guide to the birds of the Indian Subcontinent. - Yale University Pres, New Haven, New York.

Koopman, M. E. 2003. Genetic structure of boreal owls. - PhD dissertation, University of Wyoming, Laramie.

Koopman, M. E., Schable, N. A. and Glenn, T. C. 2004. Development and optimization of microsatellite DNA primers for boreal owls (Aegolius funereus). - Mol. Ecol. Notes 4: 376-378.

Korpimäki, E., Lagerström, M. and Saurola, P. 1987. Field evidence for nomadism in Tengmalm's owl Aegolius funereus. - Ornis Scand. 18: 1-4. 
Kryukov, A. P. and Suzuki, H. 2000. Phylogeography of carrion, hooded, and jungle crows (Aves, Corvidae) inferred from partial sequencing of the mitochondrial cytochrome $b$ gene. - Russian J. Genetics 36: 922-929.

Löfgren, O., Hörnfeldt, B. and Carlsson, B. -G. 1986. Site tenacity and nomadism in Tengmalm's owl (Aegolius funereus L.) in relation to cyclic food production. - Oecologia 69: 321-326.

Mysterud, I. 1970. Hypotheses concerning characteristics and causes of population movements in Tengmalm's owl (Aegolius funereus L.). - Nytt Magasin for Zoologi 18: 4974.

Omland, K. E., Tarr, C. L., Boarman, W. I., Marzluff, J. M. and Fleischer, R. C. 2000. Cryptic genetic variation and paraphyly in ravens. - Proc. R. Soc. Lond. B 267: 2475-2482.

Pyle, P. 1997. Identification guide to North American birds. - Slate Creek Press, Bolinas, CA.

Ripley, S. D. II. 1961. A synopsis of the birds of India and Pakistan, together with those of Nepal, Sikkim, Bhutan, and Ceylon. - Bombay Natural History Society, Diocesan Press, Madras, India.
Roberts, T. J. 1991. The birds of Pakistan. Vol. 1. - Oxford University Press, UK.

Sonerud, G. A., Solheim, R. and Prestrud, K. 1988. Dispersal of Tengmalm's owl Aegolius funereus in relation to prey availability and nesting success. - Ornis Scand. 19: 175-181.

Stahlecker, D. W. and Rawinski, J. W. 1990. First records for the boreal owl in New Mexico. - Condor 92: 712-716.

Weir, B. S. and Cockerham, C. C. 1984. Estimating F-statistics for the analysis of population structure. - Evolution 38: $1358-1370$.

Zink, R. M., Rohwer, S., Adreev, A. V. and Dittmann, D. L. 1995. Trans-Beringia comparisons of mitochondrial DNA differentiation in birds. - Condor 97: 639-649.

Zink, R. M., Rohwer, S., Drovetski, S., Blackwell-Rago, R. C. and Farrell, S. L. 2002. Holarctic phylogeography and species limits of three-toed woodpeckers. - Condor 104: $167-170$

(Received 28 July 2004, revised 10 December 2004, accepted 20 December 2004.) 